\title{
CLIMATE CHANGE AND
}

\section{URBANIZATION IN NEW YORK \\ CITY DURING BLOOMBERG'S Journal of Economics and Administrative Sciences \\ Vol. 36, Issue 2, 2018 \\ pp. 1-20}

Hacettepe University

\section{TERM OF MAYOR:}

\section{EFFECTS AND IMPLICATIONS}

\section{Elif ÇOLAKOĞLU}

Assoc.Prof.Dr., Security Sciences

Institute, Gendarmerie and Coast Guard

Academy, Ankara, Turkey

ecolakoglu@jandarma.gov.tr
This research was financially supported by The Scientific and Technological Research Council of Turkey (Turkish: Türkiye Bilimsel ve Teknolojik Araştırma Kurumu, TÜBITAK) BIDEB 2219. Also the work was supervised by Professor Rebecca Bratspies (bratspies@mail.law.cuny.edu) and supported by CUNY Center for Urban Environmental Reform (CUER). Errors, however, are mine alone.
1

bstract: Nowadays New York City faces sea level rise and rising temperatures which are climate changerelated challenges. To strengthen its resilience, NYC is developing plans, formulating policy goals, setting standards, and developing new institutions for environmental governance and sustainability. Locally, through PlaNYC, the NYC administration has pursued several initiatives to reduce greenhouse gas emissions, with mostly 30 percent below current levels by 2030. Since 2002, the NYC Administration stands out challenging climate change and its initiatives which are the examples of best practices at the municipal level. In this framework, this study describes the comprehensive effort to reduce greenhouse gas emissions, as well as provides NYC's climate change projections and some of the potential risks to the NYC's critical infrastructure posed by climate change. We also discuss the future of these policies that have been implemented during Bloomberg's administration term.

Keywords: Climate change, urbanization, New York City, the Bloomberg Administration. 


\title{
BLOOMBERG DÖNEMINNDE
}

\author{
NEW YORK'TA İKLİM \\ DEĞİŞIKLİĞİ VE KENTLEŞME:
Hacettepe Üniversitesi iktisadi ve Idari Bilimler Fakültesi Dergisi, Cilt 36, Sayı 2, 2018, \\ s. $1-20$
}

\section{ETKILLER VE UYGULAMALAR}

\section{Elif ÇOLAKOĞLU}

Doç.Dr., Güvenlik Bilimleri Enstitüsü, Jandarma ve Sahil Güvenlik Akademisi, Ankara, Türkiye

ecolakoglu@jandarma.gov.tr

Bu araştırma, Türkiye Bilimsel ve Teknolojik Araştırma Kurumu (English: The Scientific and Technological Research Council of Turkey) BIDEB 2219 tarafından desteklenmektedir. Aynı zamanda, Prof. Rebecca Bratspies'in (bratspies@mail.law.cuny.edu) danışmanlığında yürütülmüş ve CUNY Center for Urban Environmental Reform (CUER) tarafındandan desteklenmiştir. Ancak mevcut hatalar, tarafıma aittir.

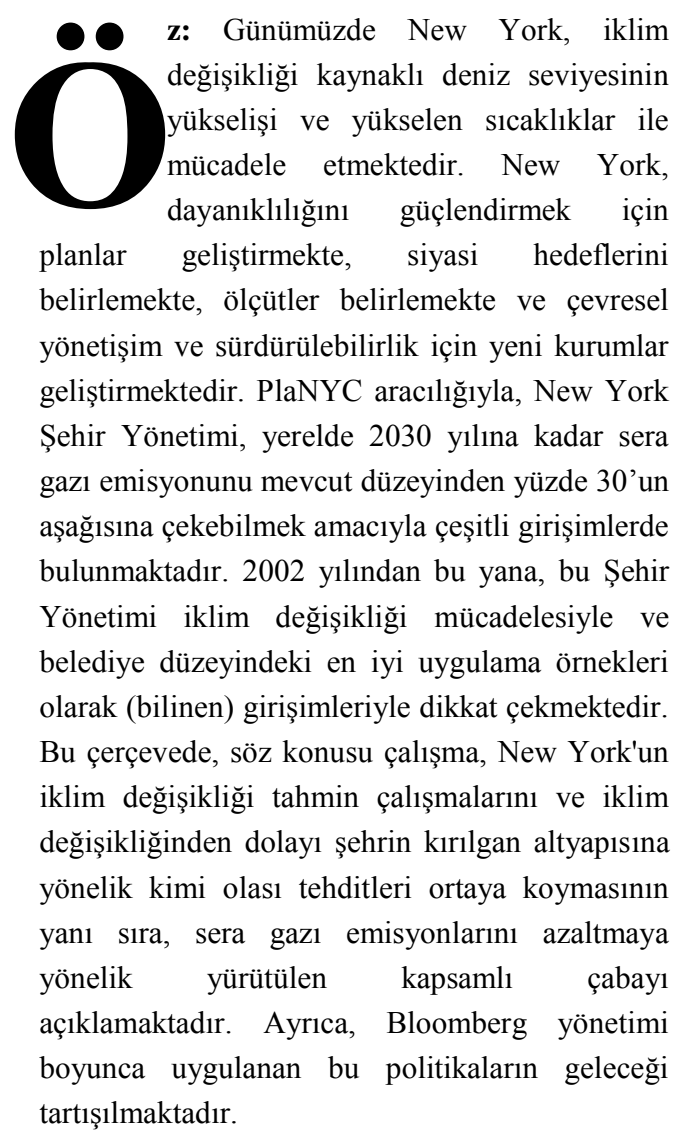

Anahtar Sözcükler: İklim değişikliği, kentleşme, New York, Bloomberg yönetimi. 


\section{INTRODUCTION}

\section{CLIMATE CHANGE AND THE NEW YORK CITY}

Today, more than before, the changing global climate is defined as a new, direct and multifaceted issue threatening national security all over the world. Considering the effects of climate change, especially through extreme weather events, the situation seems quite serious. The future of humankind and our planet may be in jeopardy due to it. Storms, droughts, forest fires and floods have caused environmental impairments and longer-lasting drought not recycled and this situation has adversely affected the food, water and sanitation security of millions of people and mass migration has happened for more than a decade. The most devastating effects of these problems are those, affecting developing countries which have scarce natural resources and limited facilities to adapt to these challenges caused by climate change. They are state's most costly and destructive natural disaster. For example, the U.S. Government has spent $\$ 350$ billion over the past decade in direct costs because of extreme weather and fire alone (Office of Management and Budget, 2016: 21). Conversely, it is possible that the problems created by climate change can lead to conflicts and tensions among the states and communities, especially in the world's most unstable regions, as well as threatening economic and political stability, peace and tranquility.

When the U.N. report (United Nations, Department of Economic and Social Affairs, June 13, 2013) explains that the world population has passed about 7 billion and that more than half of this population lives in cities, it highlights changes and trends about threats we will face. Cities have responsibility for 75 percent of the total global energy consumption and that is, for 80 percent of the world's greenhouse gas (GHG) emissions (Dodman, 2009: 6). Moreover, the world population is expected to reach 11.2 billion of this by 2100, an increase of nearly 50 percent from today's population of 7.4 billion (United Nations, Department of Economic and Social Affairs, Population Division, 2015: 1). GHG effect is felt rather in cities and has turned to be an environmental problem as a result of human activities. Because of this pollution, especially in these cities, urban heat islands occur as a result of the effect of inversion. These heat islands occur since cities get warmer than the rural areas as a result of unplanned and distorted urbanization, and it becomes a source of environmental problems from which many environmental consequences emerge. Due to the continued growth of GHG emissions, projected global average temperatures at the end of the $21^{\text {st }}$ century will be at least $4^{\circ} \mathrm{C}$ (Obama, 2017: 126).

Thus, cities and local governments that are directly affected by this process are required to cope with the natural disasters such as thirst and sudden floods - for example the European heatwave of 2003 caused 35,000 deaths, Hurricane Katrina in the U.S. in August 2005, Myanmar' Cyclone Nargis disaster in May 2008, the 2010 heavy 
floods in Pakistan, and long-term droughts in the Amazon Basin, Australia and East Africa. Given that this process is so rapid in cities like Istanbul, Ankara, and Izmir that grows rapidly the inventory of GHG in Turkey (Republic of Turkey Ministry of Forestry and Water Affairs, Turkish State Meteorological Services, 2016) must be documented as soon as possible and the re-creation of energy, agriculture and water resources must be realized, and management and planning of reduction targets should be specified and monitored. With urban infrastructure regulations created in this framework, sustainable and livable cities can be created. Sustainable cities are the locations that make socio-economic benefits available to citizens in accordance with environmental and energy concerns in order to ensure the sustainability of the rural change and development. Developments in these cities are planned to parallel sustainable social development. Accordingly, necessary measures to be taken regarding reduction and restriction of carbon emission rate used in the prevention of climate change are important in the process of creating a sustainable city.

One of New York City's ("NYC") best practices for tackling with climate change and the creating sustainable city is the NYC administration (the "Administration") and its applications. The Administration comes forward particularly in this regard to commissioning expert scientific advice, formulating policy goals, setting standards and developing new institutions for environmental governance and sustainability (Corburn, 2009: 413), although the City faces as a result of more frequent heavy precipitation, sea level rise and rising temperatures which are climate changerelated challenges. Hurricane Sandy, which occurred in October of 2012, can be an important touchstone for that and also, is a clear example for need to tackle climate change. Because this Hurricane struck and swept through the Caribbean and up the East Coast of the nation, it was the deadliest and most destructive hurricane of the 2012 Atlantic hurricane season, besides the second-costliest hurricane in the nation history. It affected 24 states, including the entire eastern seaboard from Florida to Maine and west across the Appalachian Mountains to Michigan and Wisconsin, with especially severe damage in New Jersey and New York, and caused the death of hundreds of people. Its storm surge hit NYC, flooding streets, tunnels and subway lines and cutting power in and around the city. In affected region, over 7,000 transformers and 15,200 poles were damaged and fuel pumps at gas stations did not work due to power outages and lack of back-up generation (U.S. Department of Energy, 2013: 6). It caused large financial losses; over $\$ 50$ billion in damage in the nation, total surpassed only by Hurricane Katrina. Hurricane Sandy is the nation's most expensive storm since Hurricane Katrina, which caused $\$ 128$ billion in damage, according to the 2013 data (DoSomething.Org, June 12, 2013), and this mainly will be paid by federal funds, but many other tax bills will reflect to the public (Freedman-Schnapp, August 16, 2013: 1). Despite all this, the author believes the NYC Administration was protected from the possible more adverse 
results because of the measures taken to increase the NYC's resilience to extreme weathers.

Our study examines policies and programs related to GHG emissions arising in NYC within the scope of the efforts local governments to ensure urban sustainability against the climate change. This study shows how the NYC's climate policy developed in the context of a comprehensive long-term sustainability plan and model, which is PlaNYC, since 2002. The NYC Administration stands out in challenging climate change, and its initiatives are the examples of best practices at the municipal level. In this framework, our study consists of two sections. The first section discusses NYC's administrative structure in the light of current studies. This section also provides climate change projections for NYC and identifies some of the potential risks to the city's critical infrastructure posed by climate change. In the second and final section, NYC's policies and measures for the realization of goals set for its GHG emissions reduction are analyzed.

\section{ADDRESSING CLIMATE CHANGE OF THE NEW YORK CITY ADMINISTRATION}

To begin dealing with risks posed by changing climate, NYC administration, or rather the Bloomberg administration has needed to take concrete steps to protect the City's vulnerability to climate change since 2002. The NYC administration with regard to climate change and adaptation has focused on managing and reducing effectively the City's emissions. Till today, the NYC administration has actively applied and pursued programs, and legal and policy measures to reduce emissions of GHG emissions, with mostly 30 percent below current levels by 2030. But the administrations who served in the previous terms had taken no action on this issue (Gerrard, July 12, 2013), despite their acceptance of the existence of climate change as a problem. For example, the Giuliani administration (1994-2001) opposed clearly mandatory limits on GHG emissions (Grist, July 12, 2013; Council on Foreign Relations, July 12, 2013; Lavelle and Lewis, July 12, 2013). Thus, this study discusses only the policies and practices covering the period of Mayor Michael Bloomberg (2002-2013), who was positioning the city to be a leader and a driving force in addressing climate change and sustainability planning.

\subsection{Observed Trends for Temperature, Precipitation Sea Level Rise and Extreme Events in New York City}

NYC has a temperate and continental climate, along with hot and humid summers and cold winters. An annual average air temperature from 1971 to 2000 was approximately 55 degrees Fahrenheit, according to the records. Its climate is depicted by substantial precipitation amounts range between approximately 43 and 50 inches in 
all months of the year. (NYC.gov, June 13, 2015) However the trends in temperature, precipitation and sea levels have risen overall throughout the century, despite of interannual and decadal variations. Observational records show that spring is arriving sooner, summers are growing hotter, and winters are becoming warmer and less snowy. NYC's mean annual temperature and precipitation increased, respectively, $4.4^{\circ} \mathrm{F}$ and 7.7 inches from 1900 to 2011. Moreover, a long and intense heat wave during the summer of 2006 caused 40 heat stroke deaths, most of them elderly, in NYC, according to a report (NYC Health, July 1, 2013). NPCC2' 2013 report update finds that mean annual temperatures and precipitation are, in turn, projected by global climate models to increase by $2.0-3.0^{\circ} \mathrm{F}$ and $0-10$ percent by next seven years (New York City Panel on Climate Change (NPCC2), 2013: 4). Sea level in a large fraction of NYC and the surrounding region has also risen 1.1 feet due to land subsidence, with the remaining sea level rise driven by climate-related factors since 1900 and infrastructure in these areas is vulnerable to coastal flooding during major storm events from inland flooding and coastal storm surges (NYC.gov, June 13, 2015). It is not definite due to high natural variability and limited record length (Horton et al., 2011: 2252), but this sea level rise occurring over time increased the extent and the magnitude of coastal flooding during storms. Several previous studies (U.S. Department of Energy, 2013; National Climate Assessment and Development Advisory Committee (NCADAC), 2013; Intergovernmental Panel on Climate Change, 2012; National Oceanic and Atmospheric Administration, 2012; Sallenger Jr et al., 2012: 884-888; Smith and Katz, 2013: 387 410 ) have also confirmed the claim that sea levels continue to rise globally, along with higher local rates of rise in the Northeast U.S. during this century and therefore, NYC can expect dramatic changes in climate over the course of this century, with significant impacts on the NYC's economy, environment and quality of life. All observed climate information and trends poses significant risks to NYC's communities and infrastructure.

\section{York City}

1.2. Climate Change Adaptation as a Challenge and Opportunity for New

New York City's Office of Long-Term Planning and Sustainability (OLTPS) formed as part of the Mayor's Office by the Bloomberg administration in 2006 (NYC.gov, July 5, 2013). The Office, as a comprehensive and important step toward climate change adaptation, launched a report titled PlaNYC (NYC.gov, July 3, 2013) after one year. PlaNYC was a comprehensive and long-term sustainability plan comprised of 127 initiatives in the key areas of land, water, transportation, energy, air and climate change. Since then, the plan was updated in 2011 and has been expanded to 132 initiatives and more than 400 specific milestones to prepare the city for one million more residents, strengthen the economy, combat climate change, and enhance the quality of life for all New Yorkers for December 2013 (NYC.gov, July 3, 2013). The Office has accepted that the challenges related to climate change are a part of sustainable development goals. 
Under the umbrella of NYC's sustainability plan, PlaNYC, the Bloomberg administration has carried out a wide range of innovative initiatives, including the Greener Greater Buildings Plan (GGBP), Clean Heat Program, Climate Resilience Initiatives, Million Trees program, Green Infrastructure Plan, and the others to increase NYC's resilience to the effects of climate change during this time. NYC is becoming more energy efficient with these initiatives. For example, only as more buildings comply with the GGBP and as the code proposals of the NYC Green Codes Task Force are fully enacted, it is expected that these efficiency gains would increase, and could yield more than a 10 percent GHG emissions reduction by 2030. This success has largely based on improvements in the NYC' energy supply changes. According to 2013 data, NYC's annual GHG emissions over 2005 emissions have dropped 16 percent more than halfway to its goal of a 30 percent reduction by 2030. For this, the Bloomberg administration has spent 10 percent of their annual energy budget approximately $\$ 80$ million - on funding energy efficiency measures in city government buildings so far (NYC.gov, July 8, 2013).

\subsubsection{The Greener, Greater Buildings Plan}

NYC's buildings account for about 75 percent of carbon emissions. They are the largest single source of energy use and emissions (Brokhof et al., 2011: 20), and this leads to $\$ 15$ million per year in energy costs. The city has 22,000 buildings, which are mostly concentrated in Manhattan, over 50,000 square feet, according to the records. To reduce energy consumption and make the energy systems of the city cleaner and more reliable, NYC enacted GGBP legislative package in December 2009 (Millan, July 9, 2013).

GGBP is comprised of four local laws supplemented by job training opportunities and financing entity called the New York City Energy Efficiency Corporation (NYCEEC). The regulations consist of Local Law 85 (NYC Energy Conservation Code), Local Law 84 (Energy and Water Benchmarking), Local Law 87 (Energy Audits and Retro-commissioning) and Local Law 88 (Lighting Upgrades and Sub-metering). Based on the New York State Energy Code, Local Law 85 is the City's local energy code and its provisions apply to all renovations and repairs since its adoption in 2009. Its goal is to ensure that NYC's building stock provides the benefits of energy efficiency during the natural cycles of building upgrades. Local Law 84 is the annual requirement to benchmark energy and water consumption and requires owners of large buildings to do this. About 3,000 buildings including libraries, police stations, firehouses, schools, courthouses, health, community and family centers, and government offices have been benchmarked by the NYC Department of Citywide Administrative Services, with 28 agencies, since 2009 (NYC Department of Citywide Administrative Services, 2011: 8; NYC Department of Citywide Administrative Services, July 10, 2013). Local Law 87 requires energy audits and retro-commissioning 
for large buildings which must be fulfilled for all the base building systems, consisting of HVAC, electrical and lighting, conveying systems, domestic hot water, and building envelope. Local Law 88 requires the lighting in the non-residential space be upgraded to meet code and large commercial tenants be provided with sub-meters by 2025 (NYC.gov, July 8, 2013; Brokhof et al., 2011: 6-7).

By 2030, this comprehensive plan to improve energy-efficiency in existing buildings is estimated to reduce citywide GHG emissions from new and existing buildings by at least 5.3 percent (Urban Green, July 5, 2013), have a net savings of $\$ 7$ billion, and create roughly 17,800 construction-related jobs over 10 years (NYC.gov, July 8, 2013). GGBP was developed together with PlaNYC (Brokhof et al., 2011: 5), and has been implemented successfully. This is because, by August 2011, almost twothirds of covered buildings had complied in the framework GGBP (Brokhof et al., 2011: 15). For this, NYC is also applied to use $\$ 16$ million of the $\$ 80$ million in Federal stimulus funding allocated to the city under the program of Energy Efficiency and Conservation Block Grant for this direct lending program (The Sallan Foundation, July 5, 2013). Lastly, the NYC Building Resiliency Task Force released the report which has a wide range of proposals for making NYC buildings and residents safer and better prepared for the next extreme weather event on June 27, 2013 (Urban Green Council, 2013).

\subsubsection{NYC Clean Heat Program}

NYC Clean Heat Program provides free resources to help buildings with technical assistance and financing options convert to the cleanest heating fuels including natural gas and biodiesel - from heavy heating no. 6 and no. 4 oil more quickly, beginning in July 2012. NYC Department of Environmental Protection passed the relevant regulations in April 2011. PlaNYC's goal is to reduce 2 percent of NYC's emissions, about 1.3 million metric tons, by the end of 2013 through this Program (NYC.gov, July 8, 2013). Achieving this goal will also help to improve air quality and save lives. Because NYC's air pollution leads to nearly 6 percent of annual deaths each year (New York City Department of Health and Mental Hygiene, July 10, 2013; Kheirbek et al., 2013: 477-479; Pruchnicki, 2013: 5). For this program, NYC launched more than $\$ 100$ million in financing to encourage buildings to convert to cleaner heating fuel in June 2012 (NYC.gov, July 10, 2013).

\subsubsection{Climate Resilience Initiatives}

Since 2007, the Bloomberg administration has notably taken actions to increase its resilience due to NYC's vulnerable structure which is surrounded by 520 miles of coastline, more than Miami, Boston, Los Angeles and San Francisco combined (Russ, June 12, 2013), against climate events. All these initiatives and preventions for 
rebuilding and fortifying made NYC better informed and prepared for Hurricane Sandy, but also revealed the extent of its vulnerabilities (NYC.gov, July 8, 2013), as mentioned previously.

Before taking action, the Bloomberg administration convened the New York City Panel on Climate Change (NPCC1). The Panel consists of leading climate change scientist, academics, and insurance, risk management and legal experts, with funding from the Rockefeller Foundation, in August of 2008. The main purpose of NPCC1 as the technical advisory body is to develop a clear scientific understanding of the risksbased response to climate change and possible impacts to the city's infrastructure, built environment, and population. Overseen by the Mayor's Office of Long Term Planning and Sustainability, the panel's analyses are key part of challenging climate change for the success of new initiatives from policy development to implementation, and provide facts on these issues. The NPCC1 found that NYC could encounter up to 2.5 feet of sealevel rise, almost as many 90 degree days and double to triple the probability of 100year flood of today (NYC.gov, July 8, 2013). In February of 2009, the Panel released the most detailed climate risk information for the city at the NPCC1 Report published in the Annals of the New York Academy of Sciences. To ensure long-term sustainability, ad hoc adaptation to extreme climate events are not enough, and both public and private sectors should make investments to minimize these risks mentioned. (New York City Panel on Climate Change, 2010: 1-354) And then, the administration convened over 40 public and private infrastructure operators as part of a climate change adaptation task force, the NYC's Climate Change Adaptation Task Force (CCATF), to develop an inventory of risks to the NYC's critical systems to begin addressing the risks mentioned at the report, and to coordinate between the various regional, state, and federal agencies. (NYC.gov, July 8, 2013)

In September 2012, NYC enacted Local Law 42 that established the NPCC1 as an ongoing body which meets at least twice a year, advises the NYC and the CCATF on the latest scientific developments and updates climate projections at least every three years, starting from March 2013. Following the Hurricane Sandy in October 2012, the administration reconvened secondly the New York City Panel on Climate Change (NPCC2) in January 2013 to provide current and future information and analyses concerning climate risks facing NYC for use in the Special Initiative for Rebuilding and Resiliency (SIRR), and to begin work on a new assessment. The NPCC2 which follows the risk management approach developed in NPCC1 released the NPCC Climate Risk Information report update published in June 2013. Using the latest climate models, recent observations about climate trends, and new information about GHG emissions, the NPCC2 now projects that by 2050s, sea level rises of up to 11 to 24 inches are projected. (New York City Panel on Climate Change (NPCC2), 2013: 4-7; PlaNYC, July 15, 2013: 28) 
Afterwards, the administration launched a number of initiatives to fortify the resilience of built environment, in accordance with the results and analyses. NYC created a \$2.4 billion Green Infrastructure Plan (New York City Department of Environmental Protection, 2010) to better manage rainfall and prevent the impacts of combined sewer overflows. The administration required that all projects undertaking environmental review deal with future sea level rise and coastal risks in their drafts to protect new waterfront development. Another initiative is NYC Cool Roofs Program (NYC.gov, July 17, 2013) to help cool the city and reduce cooling costs, cut energy usage and lower GHG emissions by reducing the amount of heat absorbed by buildings (Howe, 2012: 219). This program encourages building owners to cool their rooftops by applying a reflective white coating. (NYC.gov, July 8, 2013) In NYC, the total cooled roofs are nearly 3.7 million square feet in size, according to 2012 Annual Report of the NYC Department of Buildings (NYC Buildings, August 5, 2013: 28).

Lastly, the measures were taken before, during and after the Hurricane Sandy. One of them that are the Bloomberg administration in 2010 began working together the Federal Emergency Management Agency (FEMA) to update NYC's flood maps - Flood Insurance Rate Maps -, a comprehensive program to retrofit existing buildings in coastal areas. To help communities understand their coastal flood risks and determine whether buildings must obtain flood insurance and meet flood protection standards in the NYC's Building Code, the maps (Federal Emergency Management Agency, July 18, 2013) were already in the process of being updated when the hurricane struck. Also, another initiative of the administration is a comprehensive coastal protection study, officially known as the North Atlantic Coast Comprehensive Study, with the U.S. Army Corps of Engineers (USACE). Released on May 28, 2013, the USACE's this study which was authorized for up to $\$ 20$ million by Congress, and determines and evaluates how best to reduce flood and storm damage risks for vulnerable coastal people and communities in areas affected by Hurricane Sandy. (U.S. Army Corps of Engineers, July 19, 2013; U.S. Army Corps of Engineers (New York District Times), 2013: 1-16)

For this, in December 2012, the Bloomberg administration also convened the Special Initiative on Rebuilding and Resiliency (SIRR) as an effort to rebuild communities that were hit hardest by Hurricane Sandy and fortify the resilience of the built environment and critical infrastructure to the effects of changing climate. In the aftermath of Hurricane Sandy, SIRR announced a report which is the latest report under PlaNYC, recommending how to rebuild communities' post-Sandy and boost infrastructural resiliency citywide, on June 11, 2013. The plan is estimated to cost nearly \$20 billion, includes over 250 specific initiatives for preparing the NYC in the face of climate change and severe storms. (PlaNYC, July 15, 2013: 50) In general, these initiatives consist of building a huge levee to protect Lower Manhattan, forming 
wetlands along the East River and installing floodgates along Staten Island (Fleming, 2013: 31).

1.2.4. MillionTreesNYC: A PlaNYC Initiative with NYC Parks and New York Restoration Project

Citywide, NYC's tree inventory includes over 590,000 publicly managed street trees, which are distributed amongst the five boroughs - Brooklyn, 24 percent, Bronx, 10 percent, Manhattan, 8 percent, Queens, 41 percent, and Staten Island, 17 percent -. But this is not enough; there is a requirement to increase tree planting to maintain the flow of benefits provided by the urban forest currently, as explained clearly in the NYC Municipal Forest Resource Analysis 2007 report. NYC's street trees intercept 1432 gallons of stormwater annually, and are valued at $\$ 61$ per tree. Rainfall interception by trees as mini-reservoirs, controlling runoff at the source, reduces the magnitude of floods during large storms. (Peper et al., 2007) Also, these trees affect air quality, are temperature reduction and other microclimatic effects; removal of air pollutants; emission of volatile organic compounds and tree maintenance emissions; and energy conservation in buildings and consequent power plant emissions (Nowak et al., 2007: 13). Therefore, under the PlaNYC 2030, MillionTreesNYC is implemented since 2007.

MillionTreesNYC is a public - private initiative to plant one million trees by 2017 , legislation requiring the city to formulate a plan to reduce sewage overflow, and an $\$ 80$ million commitment to energy efficiency programs for city government. According to this, NYC will plant 70 percent of the trees in parks and other public spaces, while the other 30 percent will come from private organizations, homeowners, and community organizations. (MillionTreesNYC, July 15, 2013) Founded in 1995, New York Restoration Project (NYRP) which is a non-profit organization dedicated to transforming open space in underserved communities to create a greener, more sustainable NYC, is leading this initiative in partnership with the Bloomberg administration. Also the NYC Department of Parks \& Recreation (Parks), which is responsible for greening and maintaining the city's open spaces, is another partner of this project, along with the Home Depot Foundation as a financial supporter. NYC has planted more than 750,000 trees (MillionTreesNYC, July 16, 2013) across the five boroughs so far.

\subsection{The Network of C40 Cities Climate Leadership Group}

Convened in October 2005, the C40 Cities Climate Leadership Group (hereafter "C40") is a collaboration of megacities from around the world to address climate risks. This Group brings together a unique set of assets and creates a shared sense of purpose, in aligned partnership with the Clinton Climate Initiative which focuses on helping large cities reduce their GHG emissions (Clinton Foundation, July 22, 2013) since 2006, 
and also works to empower these cities to connect with each other and share technical expertise on best practices. (C40 Cities, July 22, 2013) It also has initiatives with Bloomberg Philanthropies, World Bank, ICLEI - Local Governments for Sustainability, the Carbon Disclosure Project (CDP) and Arup.

Along with the ten-member steering committee of other C40 mayors and the executive leadership team, the current chairperson of the C40 is NYC Mayor Michael Bloomberg who began in November 2010. The C40 convenes city networks to work together on seven key areas - energy efficiency, finance and economic development, measurement and planning, sustainable communities, transportation, solid waste management, water and adaptation and to hold workshops and seminars to exchange best practice. For example, energy efficiency retrofit programs - installing energy efficient light bulbs, other smart lighting mechanisms - has been implemented for existing buildings in 20 cities. Also, 10 Cities have delivered bus rapid transit (BRT) systems. Of the 16 mayors with direct power over 1.4 million taxis, 4 mayors are piloting electric taxis, while 5 mayors are taking policy measures to introduce hybrid taxis. 22 mayors have taken action to improve the cycling infrastructure. (Rio+20 United Nations Conference on Sustainable Development, July 22, 2013) Through all these networks, the C40 aims to reduce GHG emissions significantly and to provide proven models that other cities and national governments can adopt (C40 Cities Climate Leadership Group, July 23, 2013).

A total of 59 global cities - The C40 is comprised of these cities: Addis Ababa, Athens, Bangkok, Beijing, Berlin, Bogotá, Buenos Aires, Cairo, Caracas, Chicago, Delhi, Dhaka, Hanoi, Hong Kong, Houston, Istanbul, Jakarta, Johannesburg, Karachi, Lagos, Lima, London, Los Angeles, Madrid, Melbourne, Mexico City, Moscow, Mumbai, New York City, Paris, Philadelphia, Rio de Janeiro, Rome, São Paulo, Seoul, Shanghai, Sydney, Toronto, Tokyo, and Warsaw. It also has 19 affiliate cities: Amsterdam, Austin, Barcelona, Basel, Changwon, Copenhagen, Curitiba, Heidelberg, Ho Chi Mon inh City, Milan, New Orleans, Portland, Rotterdam, Salt Lake City, San Francisco, Santiago de Chile, Seattle, Stockholm, and Yokohama - (GoGreen, July 22, 2013) which represent 297 million people and generate 18 percent of global GDP and 10 percent of carbon emissions, are members of the C40. Collectively, these cities account for 4,734 actions to combat climate change, but approximately 74 percent of them have been implemented to date, according to a report (Aggarwala et al., 2011) released in June 2011.

Launched within same year, another report provides and analyzes the information on current situation of their GHG emissions, adaptation and strategy. It explains that 58 percent of the 42 reporting cities are adopting citywide GHG reduction targets, and 62 percent have established action plans to address climate change. But 
over 90 percent of $\mathrm{C} 40$ cities identified themselves as being at risk due to climate change. Also, there exists an overarching need for developing a standardized way cities can publicly communicate their carbon emissions and risk profiles, according to this report. (Carbon Disclosure Project (CDP), 2011) The reports released during the last two years have demonstrated the results from second and third year of annual reporting from cities in $\mathrm{C} 40$. The first report shows a rise in $\mathrm{C} 40$ cities setting emissions reduction targets from 62 percent in 2011 to 71 percent, as well as the measurement and reporting of citywide emissions is a growing trend among the C40 cities. These cities report emissions totaling nearly 1 billion tons of carbon emissions, which represents an increase of 43 percent from levels reported last year (Carbon Disclosure Project (CDP), 2012). Launched this year, the final report is based on data disclosed by 110 cities and shows how climate change actions are helping cities reduce carbon emissions and analyzes the current situation of these cities. According to the report findings, the cities are cutting their carbon footprint, reporting annual energy savings of up to $\$ 13$ million, and their residents are benefitting from healthier living and better business environments. Also these cities report about $\$ 40$ million in savings per year from their emissions reduction activities (Riffle et al., 2013).

Hosted by the city of Copenhagen in cooperation with the C40 cities and ICLEI, the Climate Summit of Mayors was held in December 2009 in conjunction with the $15^{\text {th }}$ Conference of the Parties (COP 15) of the United Nations Framework Convention on Climate Change (UNFCC). The goal of the Summit was to emphasize the significant role that cities play in replying to climate change in regard to both mitigation and adaptation (New York City Panel on Climate Change, 2010: 26-27). To achieve this, and create new partnerships and move forward with cutting-edge research findings, two years later, more than 30 mayors convened at the C40 Cities Mayors Summit in Sao Paulo, Brazil. ICLEI and C40 cities launched the development of a new global standard for reporting GHG emissions, as well as shared the best practices and innovation by mayors and experts from around the world (C40 Cities Climate Leadership Group, July 27, 2013). The latest C40 Mayors Summit was held on November 30-December 2, 2016.

\subsection{The Mayors Climate Protection Agreement and The Greenhouse Gas Reduction Commitment of New York City}

Another municipal network on climate change was the U.S. Conference of Mayors Climate Protection Agreement (the "Agreement"), in which cities pledged to meet or exceed the targets as set forth in the Kyoto Protocol to the United Nations Framework Convention on Climate Change, which is an international treaty that sets binding obligations on industrialized countries to reduce GHG emissions, in their own communities. Adopted in June 2005, the Agreement encourages the U.S. municipalities to take action to reduce GHG emissions and aims basically reducing the nation's 
dependence on fossil fuels and also expediting the development of clean, economical energy resources and fuel-efficient technologies. Signatories of the Agreement are represented in the Conference by its chief elected officials, the mayors (Carlarne, 2010: 91). As of August 8, 2013, the mayors of 1060 from the 50 States, the District of Columbia and Puerto Rico, representing a total population of over 89 million citizens, have signed and joined the Agreement (Mayors Climate Protection Center, August 8, 2013). Today, the total 47 cities including NYC from the state of New York have signed it (Mayors Climate Protection Center, August 9, 2013), and formally adopted and actively promoted policy positions on these issues. These cities are instituting programs to reduce GHG emissions by installing energy-efficient lighting, developing and enforcing building codes incorporating energy-efficient designs, investing in mass transit, carpooling and bicycle commuting programs, and switching over to solid waste management programs that use less energy and recovering landfill gases, as well as creating an emission inventory and developing an effective action plan to fight climate change. (Mayors Climate Protection Center, August 10, 2013; Engel and Orbach, 2008: 122-123) The NYC administration's actions at the municipal level have substantially been generated under the PlaNYC, which aims to reduce GHG emissions by 30 percent citywide, and begun implementing over 90 percent of the 127 initiatives (The United States Conference of Mayors, 2008: 11; The United States Conference of Mayors and the City of Seattle, 2007: 16-17) such as enacting a local regulation requiring the NYC's yellow cab fleet to drive only hybrid cars by 2012 (NYC.gov, August 9, 2013), and launching a campaign to plant one-million trees, with 30,800 trees planted since 2007.

\section{CONCLUSION: NEW YORK CITY CLIMATE CHANGE ADAPTATION AFTER BLOOMBERG...}

The catastrophic effects of global warming can be seen in NYC today. As of now, the NYC as a coastal city has faced different climate risks such as heat waves and storm surges, which affect everyday life citywide, and, if current trends continue, they will become more frequent and severe. Hurricane Sandy which has devastated the East Coast is just the latest example.

Being aware of these consequences, the NYC administration has taken measures both to resolve the crisis arising climate change - environmental, social and technological -, to turn to opportunities since 2002. Under PlaNYC, which could be called "ambitious", the Administration has carried out successfully initiatives such as the Greener, Greater Buildings Plan and the Million Trees Program to tackle climate change through reducing GHG emissions, with mostly 30 percent below current levels by 2030 . These initiatives, which providing the examples of best practices at the local level, help to create a more resilient the NYC, with a long-term focus on preparing for the impacts of climate change. However, the weakest side of these, maybe, is that the 
NYC has limited financial resources. This can turn a disadvantage because of other pressing needs and tight budgets.

Additionally, this strategy of the NYC administration at the local level should be transferred to the national level, and also adopted as above-party political interest, as mentioned frequently in our study. Achieving this challenge will require integration with the national preparedness system across adaptation and mitigation. In June 2013, the U.S. Government released a rebuilding strategy to strengthen all communities in the U.S. at risk from extreme weather and promised to help local governments strengthen their infrastructure (Executive Office of the President, 2013; Ernest J. Moniz's speech, 2013). Thereby, this is important in terms of additional support and guidance from the federal government. Moreover, the most recent local government elections in NYC have taken place on November 5, 2013; it is very important whether or not the current mayor has same policies. In addition, the NYC may need many more strategies in adapting citywide to a changing climate, as well as current politics. To ensure that the NYC is resilient to existing and future climate risks, the current mayor must take further action. Because NYC' mayor will have inevitably to address and tackle the complex and crucial problems and its impacts facing the city post-Sandy, and other climate change threats in the future. Aggressive administrative efforts have achieved great success.

The NYC administration is a good municipal example for the cities in Turkey, especially for its coastal cities such as Istanbul and Izmir that are vulnerable to climate change effects. This is worth considering not only in terms of best practices, but also an evidence of fulfillment the administrative success in a short period of time, the last 12 years. In fact, NYC is late relatively to address climate change, when compared to other cities such as Los Angeles, Seattle and Denver in the nation. For example, as one of the C40 cities, Istanbul, located in northwestern Turkey, is in a similar situation now, and needs to a comprehensive program which are preparing risk assessments, setting GHG emission reduction targets and pledging to act, just as the PlaNYC. The effort of NYC's administration may be able to provide lessons to our cities as they plan adaptation strategies.

\section{REFERENCES}

Aggarwala, R.T., R. Desai, B. Choy, A. Fernandez, P. Kirk, A. Lazar, T. Smith, M. Watts, A. Yan (2011), Climate Action in Megacities: C40 Cities Baseline and Opportunities, Version 1.0, ARUP \& C40 Cities Climate Leadership Group, 1-114.

Asbury H.S.J., S.D. Kara, A.H Peter (2012), "Hotspot of Accelerated Sea-Level Rise on the Atlantic coast of North America", Nature Climate Change, 2, 884-888.

Brokhof, K., B. Holland, R. Foshee (2011), Case Study: New York City's Greener, Greater Buildings Plan, ICLEI-Local Governments for Sustainability USA \& the Institute for Market Transformation. 
ÇOLAKOĞLU | Bloomberg Döneminde New York’ta İklim Değişikliği ve Kentleşme

Carbon Disclosure Project (CDP) (2011), CDP Cities 2011, Global Report on C40 Cities (Report written by KPMG), C40 Cities Climate Leadership Group, 1-38.

Carbon Disclosure Project (CDP) (2012), Measurement for Management, CDP Cities 2012 Global Report: Including Special Report on C40 Cities, C40 Cities Climate Leadership Group, 1-89.

Carlarne, C.P. (2010), Climate Change Law and Policy: EU and US Approaches, New York: Oxford University Press.

Clinton Foundation (July 22, 2013), Clinton Climate Initiative, http:// www.clintonfoundation.org/main/our-work/by-initiative/clinton-climateinitiative/about.html

Corburn, J. (2009), “Cities, Climate Change and Urban Heat Island Mitigation: Localising Global Environmental Science”, Urban Studies, 46(2), 413-427.

Council on Foreign Relations (July 12, 2013), Rudy Giuliani, http:// www.cfr.org/experts/world/rudy-giuliani/b10534\#16

C40 Cities (July 22, 2013), C40 Cities Climate Leadership Group, http:// www.c40cities.org/.

C40 Cities Climate Leadership Group (July 23, 2013), A Global Opportunity for Cities to Lead, http://c40.org/whycities

C40 Cities Climate Leadership Group (July 27, 2013), C40 Blog: Building on a legacy of action: Looking ahead to Johannesburg 2014, http://c40.org/c40blog/building-on-a-legacy-ofaction-looking-ahead-to-johannesburg-2014

Dodman, D. (2009), Paper 1: Urban Density and Climate Change, Revisited Draft- April 2, 2009 (Analytical Review of the Interaction between Urban Growth Trends and Environmental Changes), United Nations Population Fund.

DoSomething.Org (June 12, 2013), 11 Facts about Hurricane Sandy, http://www.dosomething.org/tipsandtools/11-facts-about-hurricane-sandy

Engel, K.H., B. Orbach (2008), "Micro-Motives for State and Local Climate Change Initiatives", Harvard Law \& Policy Review, 2, 119-137.

Ernest J. Moniz's speech (August 26, 2013), Policy Address by Ernest J. Moniz, U.S. Secretary of Energy, Center on Global Energy Policy, Columbia University, New York City.

Executive Office of the President (2013), The President's Climate Action Plan, 1-21.

Federal Emergency Management Agency (July 18, 2013), Flood Insurance Rate Map (FIRM): National Flood Insurance Program (NFIP) Policy Index, http://www.fema.gov/floodplai n-management/flood-insurance-rate-map-firm

Fleming, W. (2013), "Has Anything Changed? A Year After Sandy, Are We Ready for the Next Big Storm?", City \& State, 2(16), 31-32.

Freedman-Schnapp, M. (August 16, 2013), "A Sustainable City for All”, Toward a $21^{\text {st }}$ Century City for All: Progressive Policies for New York City in 2013 and Beyond, http://21c4all.org/sites/default/files/pdf/21cforall_sustainability.pdf

Gerrard, M.B. (July 12, 2013), Personal Interview (at 10:30 a.m.).

GoGreen: An Ecotribe Initiative (July 22, 2013), Green Stories: C40 Cities - Climate Leadership Group, http://www.go-green.ae/ greenstory_view.php?storyid=1375

Hacettepe Üniversitesi İktisadi ve İdari Bilimler Fakültesi Dergisi

Cilt 36, Sayı 2, 2018

16 
Grist (July 12, 2013), A look at Rudy Giuliani's environmental platform and record, http://grist.org/article/giuliani/full/

Horton, R. M., Vivien Gornitz, Daniel A. Bader, Alex C. Ruane, Richard Goldberg, Cynthia Rosenzweig (2011), "Climate Hazard Assessment for Stakeholder Adaptation Planning in New York City", Journal of Applied Meteorology Climatol, 50, 2247-2266.

Howe, J.C. (2012), "Chapter 7: Buildings", The Law of Adaptation to Climate Change: U.S. and International Aspects (edits. Michael B. Gerrard and Katrina Fischer Kuh), Chicago: American Bar Association, 209-234.

Intergovernmental Panel on Climate Change (2012), Managing the Risks of Extreme Events and Disasters to Advance Climate Change Adaptation, A Special Report of Working Groups I and II of the Intergovernmental Panel on Climate Change (edits. C.B. Field, V. Barros, T. F. Stocker and D. Qin), New York: Cambridge University Press.

Kheirbek, I., K. Wheeler, S. Walters, D. Kass, T. Matte (2013), "PM2.5 and Ozone Health Impacts and Disparities in New York City: Sensitivity to Spatial and Temporal Resolution", Air Quality, Atmosphere \& Health, 6, 473-486.

Lavelle, M., M. Lewis (July 12, 2013), Climate Change Lobbying Dominated by 10 Firms, http://www.politico.com/news/stories/ 0509/22723.html

Mayors Climate Protection Center (August 9, 2013), Cities That Have Signed On, http://www.usmayors.org/climateprotection/cities.a sp?state=NY

Mayors Climate Protection Center (August 8, 2013), Map of Participating Mayors, http://www.usmayors.org/climateprotect ion/map.asp

Mayors Climate Protection Center (August 10, 2013), The U.S. Mayors Climate Protection Agreement (As endorsed by the $73^{\text {rd }}$ Annual U.S. Conference of Mayors Meeting, Chicago, 2005),

http:// www.usmayors.org/climateprotection/documents/mcpAgreement.pdf

Millan, N. (July 9, 2013), NYC's Greener, Greater Buildings Plan, http://www.facilitiesnet.com/energyefficiency/article/NYCs-Greener-GreaterBuildings-Plan--11548

Million Trees NYC (July 15, 2013), About Million Trees NYC, http:// www.milliontreesnyc.org/html/about/about.shtml

Million Trees NYC (July 16, 2013), I'm available, http://www.million treesnyc.org/html/home/home.shtml

National Climate Assessment and Development Advisory Committee (NCADAC) (2013), National Climate Assessment, U.S. Global Change Research Program Public Review Version.

National Oceanic and Atmospheric Administration (2012), Global Sea Level Rise Scenarios for the United States National Climate Assessment, NOAA Technical Report OAR CPO-1.

New York City Department of Environmental Protection (2010), NYC Green Infrastructure Plan: A Sustainable Strategy for Clean Waterways, 1-16. 
ÇOLAKOĞLU | Bloomberg Döneminde New York’ta İklim Değişikliği ve Kentleşme

New York City Department of Health and Mental Hygiene (July 10, 2013), Air Pollution and the Health of New Yorkers: The Impact of Fine Particles and Ozone (Edit. Lise Millay Stevens),

http://www.nyc.gov/html/doh/downloads/pdf/eode/eode-air-quality-impact.pdf

New York City Panel on Climate Change, Climate Change Adaptation in New York City: Building a Risk Management Response (edits. C. Rosenzweig and W.D. Solecki) (2010), New York City Panel on Climate Change 2010 Report, In Annals of the New York Academy of Sciences, New York, 1-354.

New York City Panel on Climate Change (NPCC2) (2013), Climate Risk Information 2013. Observations, Climate Change Projections, and Maps (edits. C. Rosenzweig and W. Solecki), Prepared for use by the City of New York Special Initiative on Rebuilding and Resiliancy, New York.

Nowak, D.J., R.E. Hoehn III, D.E. Crane, J.C. Stevens, J.T. Walton (2007), Assessing Urban Forest Effects and Values: New York City's Urban Forest, U.S. Department of Agriculture, Forest Service, Northern Research Station Resource Bulletin NRS-9, Newtown Square, 1-24.

NYC Buildings (August 5, 2013), 2012 Annual Report (in April 2013), http://issuu.com/nycbuildingsannualreport2012/docs/3652_nycbuildings_annualreport2

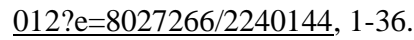

NYC Clean Heat (July 10, 2013), Technical Assistance, http://www.nyc cleanheat.org/content/technical-assistance

NYC Clean Heat (July 8, 2013), Welcome to NYC Clean Heat, http://www.nyccleanheat.org/

NYC Department of Citywide Administrative Services (2011), Energy Benchmarking Report for New York City Municipal Buildings.

NYC Department of Citywide Administrative Services (July 10, 2013), New York City Government Building Energy Benchmarking Results: 2010 and 2011, http://www.nyc.gov/html/gbee/down loads/pdf/benchmark_results_2011.pdf

NYC Health (July 1, 2013), NYC Vital Signs Investigation Reports: Deaths Associated with Heat Waves in 2006 (November 2006, Special Report),

http://www.nyc.gov/html/doh/downloads/pdf/ survey/survey-2006heatdeaths.pdf

NYC.gov (June 13, 2015), Climate Risk Information: New York City Panel on Climate Change (February 17, 2009), http:// www.nyc.gov/html/om/pdf/2009/NPCC_CRI.pdf

NYC.gov (July 8, 2013), Greener, Greater Buildings Plan, http:// www.nyc.gov/html/gbee/html/plan/plan.shtml

NYC.gov (August 9, 2013), Mayor Bloomberg Announces Taxi Fleet to Be Fully Hybrid by 2012 (May 22, 2007), http://www.nyc.gov/portal/site/nycgov/menuitem.c0935b9a57bb4ef3daf2f1c701c789a0/ index.jsp?pageID=mayor_press_release $\&$ catID $=1194 \&$ doc_name $=\mathrm{http} \% 3 \mathrm{~A} \% 2 \mathrm{~F} \% 2 \mathrm{FW}$ ww.nyc.gov\%2Fhtml\%2Fom\%2Fhtml\%2F2007a\%2Fpr156-

07.html\&cc $=$ unused $1978 \& \mathrm{rc}=1194 \&$ ndi $=1$

Hacettepe Üniversitesi İktisadi ve İdari Bilimler Fakültesi Dergisi |

Cilt 36, Sayı 2, 2018

18 
Climate Change and Urbanization in New York City During Bloomberg's... ÇOLAKOĞLU

NYC.gov (July 10, 2013), News from the Blue Room: For Immediate Release, PR-212-12, June 13,2012 ,

http://www.nyc.gov/portal/site/nycgov/menuitem.c0935b9a57bb4ef3daf2f1c701c789a0/ index.jsp?pageID=mayor_press_release $\&$ cat ID $=1194 \&$ doc name $=$ http $\% 3 \mathrm{~A} \% 2 \mathrm{~F} \% 2 \mathrm{FW}$ ww.nyc.gov\%2Fhtml\%2Fom\%2Fhtml\%2F2012a\%2Fpr212-

$12 . \mathrm{html} \& \mathrm{cc}=$ unused $1978 \& \mathrm{rc}=1194 \& \mathrm{ndi}=1$

NYC.gov (July 3, 2013), PlaNYC: A Greener, Greater New York, http:// nytelecom.vo.llnwd.net/o15/agencies/planyc2030/pdf/full report 2007.pdf

NYC.gov (July 3, 2013), PlaNYC Progress Report 2013: A Greener, Greater New York, http://nytelecom.vo.llnwd.net/o15/

agencies/planyc2030/pdf/planyc_progress_report_2013.pdf

NYC.gov (July 17, 2013), Welcome to NYC Cool Roofs, http://www.n yc.gov/html/coolroofs/html/home/home.shtml

NYC.gov (July 5, 2013), Who We Are, http://www.nyc.gov/html/plany c2030/html/about/whowe-are.shtml

Obama, B. (2017), “The Irreversible Momentum of Clean Energy”, Science, 355(6321): 126-129.

Office of Management and Budget (2016), Budget of the U.S. Government (Fiscal Year 2017), Washington.

Peper, P.J., E.G. McPherson, J.R. Simpson, S.L. Gardner, K.E. Vargas, Q. Xiao (2007), New York City, New York Municipal Forest Resource Analysis (Technical Report), Center for Urban Forest Research, U.S. Department of Agriculture, Forest Service, Pacific Southwest Research Station, 1-66.

PlaNYC (July 15, 2013), A Stronger, More Resilient New York (June 11, 2013), http://nytelecom.vo.llnwd.net/o15/agencies/sirr/SIRR_s preads_Hi_Res.pdf

Pruchnicki, A. (2013), "East vs. West, One More Imbalance”, WestView News, 9(8), 5.

Republic of Turkey Ministry of Forestry and Water Affairs, Turkish State Meteorological Services (2016), State of the Climate in Turkey in 2015, Ankara.

Riffle, C., K. Appleby, P. Martin (2013), Wealthier, Healthier Cities: How climate change action is giving us wealthier, healthier cities, based on the CDP responses from 110 global cities, Carbon Disclosure Project (CDP) \& C40 Cities Climate Leadership Group, 1-15.

Rio+20 United Nations Conference on Sustainable Development (July 22, 2013), An 'Alternative Approach for Cities': C40 Cities Climate Leadership Group Submission to Rio+20, http://

www.uncsd2012.org/content/documents/244C40\%20Submission\%20to\%20Rio20.pdf

Russ, H. (June 12, 2013), NYC Lays Out \$20 Billion Plan to Adapt to Climate Change, http://www.reuters.com/article/2013/06/11/us-climate-newyork-planidUSBRE95A10120130611

Sallenger Jr, Asbury H. , Kara S. Doran, Peter A. Howd, "Hotspot of accelerated sea-level rise on the Atlantic coast of North America", Nature Climate Change, Vol. 2, 2012, 884-888.

Smith, A.B., R.W. Katz (2013), "US billion-dollar weather and climate disasters: data sources, trends, accuracy and biases", Natural Hazards, 67(2), 387-410.

Hacettepe University Journal of Economics and Administrative Sciences | Vol 36, Issue 2, 2018 
ÇOLAKOĞLU | Bloomberg Döneminde New York’ta İklim Değişikliği ve Kentleşme

The Sallan Foundation (July 5, 2013), Greener, Greater Buildings Plan, http://sallan.org/pdfdocs/Greener_Greater_workforce_and_financing.pdf

The United States Conference of Mayors and the City of Seattle (2007), Climate Protection Strategies and Best Practices Guide: 2007 Mayors Climate Protection Summit Edition (November 1-2, Seattle), Mayors Climate Protection Center, Washington, D.C.,1-65.

The United States Conference of Mayors (2008), Climate Protection Featuring 2008 Mayors' Climate Protection Award Winning Entries, Mayors Climate Protection Center, Washington, D.C., 1-26.

United Nations, Department of Economic and Social Affairs, Population Division (2015), World Population Prospects: The 2015 Revision, Key Findings and Advance Tables, Working Paper No. ESA/P/WP.241.

United Nations, Department of Economic and Social Affairs (June 13, 2013), World Urbanization Prospects, the 2011 Revision, http://esa.un.org/unup/CD-ROM/UrbanAgglomerations.htm

Urban Green (July 5, 2013), Advocacy in Action: Urban Green Council and the Greener, Greater Buildings Plan, http://www.urban greencouncil.org/GGBP

Urban Green Council (2013), Building Resiliency Task Force: Full Proposals (Report to Mayor Michael R. Bloomberg \& Speaker Christine C. Quinn), New York.

U.S. Army Corps of Engineers (July 19, 2013), Evaluating North Atlantic Coastal Risks: North Atlantic Coast Comprehensive Study,

http://www.nad.usace.army.mil/Missions/CivilWorks/HurricaneSandyCoastalRecovery/ NorthAtlanticComprehensiveStudy.aspx

U.S. Army Corps of Engineers (New York District Times) (2013), Army Corps Responds to Hurricane Sandy, New York, 1-16.

U.S. Department of Energy (2013), U.S. Energy Sector Vulnerabilities to Climate Change and Extreme Weather (DOE/PI-0013), 1-46. 